Original Article

\title{
Diversity of fungi obtained from bats captured in urban forest fragments in Sinop, Mato Grosso, Brazil
}

\author{
Diversidade de fungos em morcegos de fragmentos florestais urbanos de Sinop, Mato \\ Grosso, Brasil
}

\author{
L. Ludwiga (D), J. Y. Muraokab (D), C. Bonacorsib (D) and F. C. Donofrio ${ }^{a *}$ (D) \\ aUniversidade Federal de Mato Grosso - UFMT, Instituto de Ciências da Saúde, Laboratório de Análises Microbiológicas e Parasitológicas - \\ LAMP, Sinop, MT, Brasil \\ bUniversidade Federal de Mato Grosso - UFMT, Instituto de Ciências da Saúde, Laboratório de Análises Clínicas, Sinop, MT, Brasil
}

\begin{abstract}
Bats are important for the homeostasis of ecosystems and serve as hosts of various microorganisms including bacteria, viruses, and fungi with pathogenic potential. This study aimed to isolate fungi from biological samples obtained from bats captured in the city of Sinop (state of Mato Grosso, Brazil), where large areas of deforestation exist due to urbanization and agriculture. On the basis of the flow of people and domestic animals, 48 bats were captured in eleven urban forest fragments. The samples were processed and submitted to microbiological cultures, to isolate and to identify the fungal genera. Thirty-four (70.83\%) of the captured bats were positive for fungi; 18 (37.5\%) and 16 (33.33\%) of these bats were female and male, respectively. Penicillium sp., Scopulariopsis sp., Fusarium sp., Aspergillus sp., Alternaria sp., Cryptococcus sp., Trichosporon sp., and Candida sp., which may cause opportunistic infections, were isolated. The bat species with the highest number of fungal isolates was Molossus molossus: 21 isolates (43.8\%). According to our results, bats captured in urban forest fragments in Sinop harbor pathogenic fungi, increasing the risk of opportunistic fungal infections in humans and domestic animals.
\end{abstract}

Keywords: biological samples, urban forest fragments, opportunistic fungus.

\begin{abstract}
Resumo
Os morcegos apresentam grande importância na homeostasia dos ecossistemas e são hospedeiros de uma rica diversidade de micro-organismos como bactérias, vírus e fungos com potencial patogênico. Portanto, este estudo visou isolar fungos presentes em amostras biológicas de morcegos na cidade de Sinop - MT, que possui grandes áreas de desmatamento devido à urbanização e agricultura. Foram capturados 48 morcegos de diferentes espécies, em onze fragmentos florestais urbanos definidos de acordo com fluxo de pessoas e animais domésticos, para obtenção de amostras biológicas. Essas amostras foram processadas e submetidas aos cultivos microbiológicos, para isolamento e identificação dos gêneros dos fungos. Dos 48 morcegos, 34 (70,83\%) foram positivos para pelos menos um gênero de fungo, sendo 18 (37,5\%) fêmeas e 16 (33,33\%) machos, e os gêneros isolados a partir das amostras biológicas foram Penicillium sp., Scopulariopsis sp., Fusarium sp., Aspergillus sp., Alternaria sp., Cryptococcus sp., Trichosporon sp. e Candida sp., que podem ser causadores de infecções oportunistas. Desse total, a espécie que apresentou maior positividade para pelo menos um gênero de fungo foi Molossus molossus com 21 (43,8\%). Nossos resultados demonstram que os morcegos capturados nos fragmentos florestais urbanos na cidade de Sinop - MT, podem atuar como agentes veiculadores de fungos com potencial patogênico, aumentando assim o risco de exposição e aquisição de infecções fúngicas oportunistas por pessoas e animais domésticos.
\end{abstract}

Palavras-chave: amostras biológicas, fragmentos florestais urbanos, fungos oportunistas.

\section{Introduction}

Urbanization transforms habitats and landscapes where wild animals live (Stone et al., 2009; Perugini et al., 2011; Francis and Barber, 2013). This process is characterized by rapid intensification of agriculture, socioeconomic changes, and ecological fragmentation and may dramatically impact the epidemiology of infectious diseases (Hassell et al., 2017). Among the infectious disease vectors associated with urban environments, bats are one of the most important.

In Brazil, bats of the suborder Microchiroptera inhabit all the national territory, from the Amazon to the pampas of Rio Grande do Sul, including urban areas. This suborder comprises 174 registered species, 65 genera, and 9 families (Paglia et al., 2012).

Studies have shown that bats harbor infectious agents, including viruses, bacteria, protozoa, and fungi (Barros et al., 2008; Cordeiro et al., 2012). Microorganisms can be spread

*e-mail: fabcrisdon@yahoo.com.br

Received: January 26, 2021 - Accepted: March 9, 2021 
through bat feces or decomposing carcasses (Voyron et al., 2011). Therefore, bats have become an important source of environmental contamination because they can travel long distances (Brilhante et al., 2016).

In 1958, Emmons described the interaction between pathogenic fungi and bats for the first time. This author demonstrated that Histoplasma capsulatum was present in samples collected from soil adjacent to buildings colonized by bats (Emmons, 1958). Since then, other researchers have studied the interaction between fungi and urban bats and have isolated Paracoccidioides brasiliensis (Grose and Tamsitt, 1965; Greer and Bolaños, 1977), Histoplasma capsulatum (Dias et al., 2011; Veloso et al., 2014), Coccidioides posadasii (Cordeiro et al., 2012), Cryptococcus sp. (Tencate et al., 2012), Pneumocystis sp. (Veloso et al., 2014), Trichosporon sp. (Brilhante et al., 2016), Candida sp. (Botelho et al., 2012; Tencate et al., 2012; Brilhante et al., 2016), and Aspergillus sp. and Penicillium sp. (Tencate et al., 2012).

Sinop, a city in the state of Mato Grosso, Brazil, is located in the region known as the Arch of Deforestation. This region contains a few environmental reserves as well as large deforestation areas due to urbanization and agriculture. The population of this county and region lives in the rural area, close to forest areas. People living in urban areas with forest remnants and forest reserves, or even in fully urbanized areas can be a target for different types of fungal infections as a result of rapid expansion of peripheries, deforestation, extractivism, agriculture, livestock, and ecotourism (Brum et al., 2011).

This study aimed to isolate and to identify fungal genera from biological samples obtained from bats inhabiting urban forest fragments in Sinop in order to understand their role in the epidemiological axis of fungal spread. This understanding is relevant to predict the transmission of infectious diseases in cities located in areas of strong agricultural expansion.

\section{Material and Methods}

\subsection{Study area}

The city of Sinop, state of Mato Grosso, Brazil, was founded in 1974. It has approximately 113,099 inhabitants in an area of $3,942,229 \mathrm{~km}^{2}$. The climate is warm, and the average annual temperature is $28{ }^{\circ} \mathrm{C}$. The rain regime is equatorial, which is characterized by a dry period in the winter and a rainy period in the summer, mainly between January and March (IBGE, 2010). The bats were captured from April to October 2017 in four urban fragments of the city. More specifically, the bats were captured in roof spaces (under a roof tile or lead flashing, between gaps in mortar, or behind fascias and soffits) and seven forest fragments in Sinop.

\subsection{Bat capture and extraction of biological samples}

This study was approved by the Ethics Committee for the Use of Animals (CEUA) of the Federal University of Mato Grosso (UFMT), Cuiabá, state of Mato Grosso, Brazil (Process No. 23108.720818/2016-15) and by the
Ministry of the Environment - MMA, Chico Mendes Institute for Biodiversity Conservation - ICMBio (Process No. 53484-1/2016). The bats were captured with 36-mm mesh mist nets measuring $9 \times 2.5 \mathrm{~m}$. The nets were opened at ground level along forest edges, on established trails, over water bodies, and close to trees (Esbérard, 2003). The bats were captured throughout the night and in all moon phases. The bat species were characterized according to the identification keys of Reis et al. (2013). After being captured, the bats were anesthetized and killed according to Normative Resolution 13/2013 of the National Council for Control of Animal Experimentation (CONCEA) (Brasil, 2013). The bats and blood samples were identified and transported to the laboratory for processing.

\subsection{Biological sample processing and identification of genera of filamentous and yeast fungi}

Samples of bat intestine, lungs, spleen, liver, and blood were obtained as described by Tencate et al. (2012) with some modifications. The samples were individually macerated in sterile $0.85 \%$ sodium chloride solution and vigorously homogenized for $5 \mathrm{~min}$. After $30 \mathrm{~min}, 100 \mu \mathrm{L}$ of each supernatant was spread over the surface of modified Sabouraud Dextrose agar plus chloramphenicol (40 mg/L) (SBR) (Sigma-Aldrich, St. Louis-MO, USA) and incubated in B.O.D. chamber (Solab, SL200/300) at $25^{\circ} \mathrm{C}$.

The supernatants $(100 \mu \mathrm{L})$ were also spread over the surface of Brain Heart Infusion (BHI) agar (Kasvi, Curitiba-PR, Brazil) plus 5\% defibrinated sheep blood (Newprov, Pinhais-PR, Brazil) and incubated in bacteriological chamber at $37{ }^{\circ} \mathrm{C}$. Before the cultures were considered negative for the presence of fungi, they were observed daily for 30 days to verify fungal growth. The blood smear was stained in panopticus and observed with a 100X immersion objective (Opton, TNB-01B-INF LED).

The fungal genera were identified by macro- and microscopic observations, namely morphology of hyphae, conidia, or spores and colonies that grew on the culture media. The filamentous fungi were identified by using diagnostic keys and descriptions reported by Pitt and Hocking (2009) and Watanabe (2010). The yeast-like fungi were identified by employing the diagnostic key and descriptions published by Kurtzman and Fell (1998).

\section{Results}

A total of 48 bats belonging to six species were captured. Among the captured bats, 35 (72.9\%) and 13 (27.1\%) belonged to the family Molossidae and Phyllostomidae, respectively, and 28 (58.3\%) and 20 (41.7\%) were female and male, respectively. The bats were naturally distributed throughout the urban and forest fragments in Sinop, state of Mato Grosso, Brazil. The dominant insectivorous species was Molossus molossus (31 bats, or 64.6\%), followed by Phyllostomus hastatus ( 7 bats, or 14.6\%). Artibius obscurus, a frugivorous species, was less frequent ( 2 bats, or $4.2 \%$ ) (Table 1).

Among the 48 bats evaluated via microbiological culture of lungs, spleen, liver, blood, and intestine, $70.83 \%$ (34 bats, 18 females and 16 males) were positive for at least one 
fungal genus; some bats presented more than one fungus (Table 2). Molossus molossus was the bat species with the highest number of bats presenting fungal isolates (21 bats, 14 females and 7 males), followed by Phyllostomus hastatus ( 6 males), Tonatia bidens ( 3 bats, 2 females and 1 male), Tadarida brasiliensis ( 2 bats, 1 male and 1 female), Artibeus obscurus (1 male), and Lophostoma brasiliense (1 male) (Figure 1).

Table 3 lists results for bat organs and viscera. Among the bats that harbored fungi, 54.2\% (26 bats, 13 females and 13 males) were positive for Penicilium sp.; 4.17\% ( 2 bats, 1 female and 1 male) for Alternaria sp., 16.7\% ( 8 bats, 4 females and 4 males) for Fusarium sp., 27.1\% (13 bats, 5 females and 8 males) for Aspergillus sp., 4.16\% (2 males) for Candida albicans, 8.33\% (4 bats, 3 females and 1 male) for Candida parapsilosis, 4.16\% (2 males) for
Candida glabrata, 8.33\% (4 bats, 2 females and 2 males) for Cryptococcus sp., 6.25\% (3 males) for Scopulariopsis sp., and $2.08 \%$ ( 1 female) for Trichosporon sp.

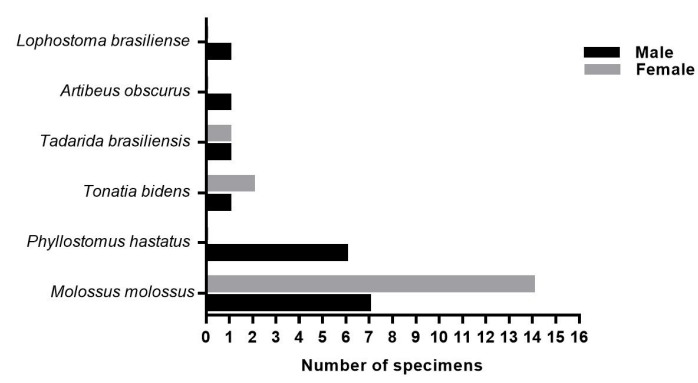

Figure 1. Bats species colonized by fungus.

Table 1. Species of bats, trophic/foraging guild and sex, capture site of Sinop, Mato Grosso, Brazil.

\begin{tabular}{|c|c|c|c|c|c|c|}
\hline \multirow{4}{*}{ Taxon } & \multicolumn{4}{|c|}{ Capture Site } & \multirow{4}{*}{ Guilds } & \multirow{4}{*}{$\%$} \\
\hline & \multicolumn{2}{|c|}{ Forest fragments } & \multicolumn{2}{|c|}{ Urban fragments } & & \\
\hline & Female & Male & Female & Male & & \\
\hline & $(\mathbf{n})$ & (n) & (n) & (n) & & \\
\hline \multicolumn{7}{|l|}{ Family Phyllostomidae } \\
\hline Lophostoma brasiliense & 1 & & & & $\mathbf{I}$ & $2.08 \%$ \\
\hline Artibeus obscurus & & 2 & & & $\mathbf{F}$ & $4.16 \%$ \\
\hline Tonatia bidens & & & 2 & 1 & I & $6.25 \%$ \\
\hline Phyllostomus hastatus & & 5 & & 2 & $\mathbf{I}$ & $14.6 \%$ \\
\hline \multicolumn{7}{|l|}{ Family Molossidae } \\
\hline Tadarida brasiliensis & 1 & 2 & 1 & & I & $8.33 \%$ \\
\hline Molossus molossus & 17 & 5 & 6 & 3 & I & $64.6 \%$ \\
\hline Total & 19 & 14 & 9 & 6 & & $48 / 100 \%$ \\
\hline
\end{tabular}

$\mathrm{n}$ = number of specimens; $\mathrm{I}$ = insectivores; $\mathrm{F}$ = frugivores.

Table 2. Fungi isolated from bats of Sinop, Mato Grosso, Brazil.

\begin{tabular}{|c|c|c|c|c|c|c|c|c|c|c|c|c|}
\hline \multirow[t]{2}{*}{ Fungi } & \multicolumn{2}{|c|}{$\begin{array}{c}\text { Tadarida } \\
\text { brasiliensis }\end{array}$} & \multicolumn{2}{|c|}{$\begin{array}{l}\text { Molossus } \\
\text { molossus }\end{array}$} & \multicolumn{2}{|c|}{$\begin{array}{l}\text { Tonatia } \\
\text { bidens }\end{array}$} & \multicolumn{2}{|c|}{$\begin{array}{c}\text { Phyllostomus } \\
\text { hastatus }\end{array}$} & \multicolumn{2}{|c|}{$\begin{array}{l}\text { Artibeus } \\
\text { obscurus }\end{array}$} & \multicolumn{2}{|c|}{$\begin{array}{c}\text { Lophostoma } \\
\text { brasiliense }\end{array}$} \\
\hline & $\mathbf{M}$ & $\mathbf{F}$ & $\mathbf{M}$ & $\mathbf{F}$ & $\mathbf{M}$ & $\mathbf{F}$ & M & $\mathbf{F}$ & M & $\mathbf{F}$ & M & $\mathbf{F}$ \\
\hline Penicillium sp. & & 1 & 7 & 12 & 1 & & 4 & & & & 1 & \\
\hline Alternaria sp. & & & 1 & 1 & & & & & & & & \\
\hline Fusarium sp. & 1 & 1 & 2 & 3 & & & & & 1 & & & \\
\hline Aspergillus sp. & & & 7 & 5 & & & 1 & & & & & \\
\hline Candida albicans & & & 1 & & & & 1 & & & & & \\
\hline Candida glabrata & & & & & & & 2 & & & & & \\
\hline Candida parapsilosis & & 1 & & 2 & & & 1 & & & & & \\
\hline Cryptococcus spp. & & & 1 & 2 & & & 1 & & & & & \\
\hline Scopulariopsis sp. & & & 1 & & 1 & & 1 & & & & & \\
\hline Trichosporon sp. & & & & & & 1 & & & & & & \\
\hline
\end{tabular}

$\mathrm{M}=$ number of males; $\mathrm{F}=$ number of females. 
Table 3. Fungal colonization in multiple bat organs and viscera.

\begin{tabular}{|c|c|c|c|c|}
\hline \multirow{3}{*}{ Fungi } & \multicolumn{4}{|c|}{ Origin of isolate } \\
\hline & $\begin{array}{l}\text { Lungs/ Liver/ } \\
\text { Spleen }\end{array}$ & Intestine & Blood & $\%$ \\
\hline & (n) & (n) & (n) & \\
\hline Penicillium sp. & $\mathbf{0}$ & 26 & $\mathbf{0}$ & $54.2 \%$ \\
\hline Alternaria sp. & $\mathbf{0}$ & 2 & $\mathbf{0}$ & $4.17 \%$ \\
\hline Fusarium sp. & $\mathbf{0}$ & 8 & $\mathbf{0}$ & $16.7 \%$ \\
\hline Aspergillus sp. & $\mathbf{0}$ & 13 & $\mathbf{0}$ & $27.1 \%$ \\
\hline Candida albicans & $\mathbf{0}$ & 2 & $\mathbf{0}$ & $4.16 \%$ \\
\hline Candida glabrata & $\mathbf{0}$ & 2 & $\mathbf{0}$ & $4.16 \%$ \\
\hline Candida parapsilosis & 2 & 2 & $\mathbf{0}$ & $8.33 \%$ \\
\hline Cryptococcus sp. & 3 & 1 & $\mathbf{0}$ & $8.33 \%$ \\
\hline Scopulariopsis sp. & 1 & 2 & $\mathbf{0}$ & $6.25 \%$ \\
\hline Trichosporon sp. & $\mathbf{0}$ & $\mathbf{0}$ & 1 & $2.08 \%$ \\
\hline
\end{tabular}

$\mathrm{n}=$ number of specimens.

\section{Discussion}

We isolated genera of opportunistic pathogenic fungi from biological samples obtained from bats captured in the urban forest fragments in Sinop, state of Mato Grosso, Brazil. This region has undergone accelerated urban growth due to agricultural expansion. Urbanization, which led to the emergence of buildings and other human constructions such as bridges and tunnels, must have modified the ecology of bats drastically, as evidenced by the number of species that are currently dominant or exclusive in these structures. Human construction may simulate the structural and functional properties found in caves or trees, so bats may have learned to explore the new artificial roosting environment (Russo and Ancillotto, 2015).

In our study, the most frequent bat species was Molossus molossus, which corresponded to 31 (64.6\%) of the captured specimens and are the most prevalent in urban areas (Canteros et al., 2005; Dias et al., 2011). The presence of bats in domiciliary areas of the city of Sinop indicates interspecies contact with man and other animals, which may cause public health problems. Given that the city's illumination attracts a large number of insects, the predominance of this insectivorous species in an urban area can be explained by the shelter and food supply (Pacheco et al., 2010).

Being the most prevalent, the species Molossus molossus presented the greatest diversity of fungi: seven fungal genera were isolated from these bats. In 2017, Paz reported similar findings-this author verified that Molossus molossus was the species with the highest positivity for Histoplasma capsulatum, Paracoccidioides brasiliensis, and Cryptococcus spp. (Paz, 2017). In 2013, Corrêa et al. (2013) reported that Molossus molossus and Artibeus lituratus were the species infected with the highest number of pathogens. Molossids have been described as the most frequent bats in buildings (Pacheco et al., 2010), especially under roofs, in various structures, and in tree cavities (Reis et al., 2007).
In the present study, 35(72.92\%) of the captured bats were molossids (Molossus molossus and Tadarida brasiliensis).

In addition to molossids, other bats like Phyllostomus hastatus, Tonatia bidens, Artibeus obscurus, and Lophostoma brasiliense have been described to harbor fungi. In 2017, Paz confirmed systemic infection of lungs, liver, spleen, and intestines obtained from six bats: four, one, and one had Histoplasma capsulatum, Cryptococcus sp., and Paracoccidioides brasiliensis, respectively. In 1982, Mok et al. (1982) isolated 186 fungi from viscera, lungs, and livers obtained from 155 bats and identified seven species that were potentially pathogenic to humans including Candida parapsilosis, Candida glabrata, Candida albicans, Candida stellatoidea, Candida kefyr, and Trichosporon beigelii. In 1994, Oyeka studied 120 Nigerian bats and isolated 18 yeasts of the genera Candida sp. and Trichosporon sp. from them (Oyeka, 1994).

Several emerging diseases are zoonoses, and bats play an important role as a source of infection and transmission of infectious agents due to their social, biological, and immunological characteristics (Hance et al., 2006; Han et al., 2015; Zanella, 2016).

Regarding the biological samples obtained from bats captured in Sinop, the most isolated genera of filamentous fungi were Penicillium sp. (26, or 54.2\%) and Aspergillus sp. (13, or $27.1 \%)$. Similar findings were reported in 2003 by Rezende et al. (2003) in Bonito, state of Mato Grosso do Sul; in 2002 by Tencate et al. (2012) in the Northwestern region of the state of São Paulo; and in 2016 by Misra and Elangovan (2016) at several historical monuments in India.

Here, the most isolated opportunistic yeasts were Candida albicans (4.16\%), Candida parapsilosis (8.33\%), and Candida glabrata (4.16\%), followed by Cryptococcus sp. (8.33\%) and Trichosporon sp. (2.08\%). In 2011, Botelho et al. (2012) obtained similar results when they isolated fecal samples obtained from urban bats inhabiting the city of Londrina, state of Paraná, to detect five species of the genus Candida: Candida guilliermondii, Candida krusei, Candida 
lusitaniae, Candida parapsilosis, and Candida pelliculosa. In 2012, Tencate et al. (2012) isolated the gastrointestinal microbiota from bats in the Northwestern region of the state of São Paulo, to find yeasts of the genera Candida sp. (10\%) and Cryptococcus sp. (2\%). In 2005, Sugita et al. (2005) evaluated fecal samples obtained from volcanic cave bats captured in 11 cities in Japan and isolated nine species-two known as Trichosporon sp., and seven potentially new species as revealed by molecular phylogenetic analyses.

Yeasts of the genera Cryptococcus sp., Candida sp., and Trichosporon sp. can be found in the gastrointestinal microbiota and viscera of chiroptera; these species can infect humans through inhalation of fungal propagules present in the environment (Baltazar and Ribeiro, 2008). This contact causes opportunistic infections in immunocompromised patients exposed to a wide range of risk factors (Peixoto et al., 2014; Gibson and Johnston, 2015; Mattede et al., 2015).

Our results demonstrate that bats captured in urban forest fragments in Sinop can act as hosts of fungi with pathogenic potential. This increases the risk of human and domestic animal exposure and acquisition of opportunistic fungal infections because the bats remain in shelters close to the population.

\section{Acknowledgements}

This study was partly financed by Coordenação de Aperfeiçoamento de Pessoal de Nível Superior (CAPES) Brasil - Finance Code 001.

\section{References}

BALTAZAR, L.M. and RIBEIRO, M.A., 2008. First isolation of Cryptococcus gatti from the environment in the State of Espírito Santo. Revista da Sociedade Brasileira de Medicina Tropical, vol. 41, no. 5, pp. 449-453. http://dx.doi.org/10.1590/S003786822008000500003.

BARROS, J.H.S., ROMIJN, P.C., BAPTISTA, C., PINTO, S.G.S. and MADEIRA, M.F., 2008. Relato de infecção natural de morcegos por flagelados tripanosomatideos em diferentes municípios do Estado do Rio de Janeiro. Revista da Sociedade Brasileira de Medicina Tropical, vol. 41, no. 6, pp. 683-685. http://dx.doi. org/10.1590/S0037-86822008000600025. PMid:19142454.

BOTELHO, N.S., DE PAULA, S.B., PANAGIO, L.A., PINGE-FILHO, P., YAMAUCHI, L.M. and YAMADA-OGATTA, S.F., 2012. Candida spécies isolated from urban bats of Londrina-Paraná, Brazil and their potential virulence.Zoonoses and Public Health, vol. 59, no. 1, pp. 16-22. http://dx.doi.org/10.1111/j.1863-2378.2011.01410.x. PMid:21824363.

BRASIL. Conselho Nacional de Controle de Experimentação Animal CONCEA, 2013 [viewed 13 September 2013]. Resolução normativa $n^{\circ}$ 13, de 20 de setembro de 2013. Diretrizes da Prática de Eutanásia do CONCEA [online]. Diário Oficial da República Federativa do Brasil, Brasilia, 26 set. Available from: https://www.mctic.gov. br/mctic/opencms/legislacao/outros_atos/resolucoes/migracao/ Resolucao_Normativa_CONCEA_n_13_de_20092013.html

BRILHANTE, R.S.N., MAIA-JÚNIOR, J.E., OLIVEIRA, J.S., GUEDES, G.M.M., SILVA, A.L., MOURA, F.B.P., SALES, J.A., CASTELO-BRANCO, D.S.C.M., SIDRIM, J.J.C., CORDEIRO, R.A., PEREIRA-NETO, W.A. and ROCHA, M.F.G., 2016. Yeasts from the microbiota of bats: a focus on the identification and microbial susceptibily of a cryptic species of Candida. Journal of Medical Microbiology, vol. 65, no. 10, pp. 1225-1228. http://dx.doi.org/10.1099/ jmm.0.000340. PMid:27542964.

BRUM, A.L., DALFOVO, W.C.T. and BENFICA, V.C., 2011. A relação entre o desmatamento e o crescimento das culturas de grãos no município de Sinop-MT: uma análise para o período de 1984 a 2009. Desenvolvimento em Questão, vol. 9, no. 17, pp. 159-190. http://dx.doi.org/10.21527/2237-6453.2011.17.159-190.

CANTEROS, C.E., LACHINI, R.H., VACCARO, O., MADARIAGA, J., GALARZA, R., SNAIDERMAN, L., MARTÍNEZ, M., PALADINO, M., CICUTTIN, G., VARELA, E., ALCOBA, E., ZUIANI, F., SAHAZA, J.H., TAYLOR, M.L. and DAVEL, G., 2005. First isolation of Histoplasma capsulatum from the urban bat Eumops bonariensis. Revista Argentina de Microbiología, vol. 37, no. 1, pp. 46-56. PMid:15991479.

CORDEIRO, R.A., SILVA, K.R., BRILHANTE, R.S.N., MOURA, F.B.P., DUARTE, N.F.H., MARQUES, F.J.F., CORDEIRO, R.A., MOREIRAFILHO, R.E., ARAÚJO, R.W.B., BANDEIRA, T.J.P.G., ROCHA, M.F.G. and SIDRIM, J.J.C., 2012. Coccidioides posadasii infection in bats, Brazil. Emerging Infectious Diseases, vol. 18, no. 4, pp. 668-670. http://dx.doi.org/10.3201/eid1804.111641. PMid:22469192.

CORREA, M.M.O., LAZAR, A., DIAS, D. and BONVICINO, C.R., 2013. Quirópteros hospedeiros de zoonoses no Brasil. Boletim da Sociedade Brasileira de Mastozoologia, vol. 67, pp. 23-38.

DIAS, M.A.G., OLIVEIRA, R.M.Z., GIUDICE, M.C., NETTO, H.M., JORDÃO, L.R., GRIGORIO, I.M., ROSA, A.R., AMORIM, J., NOSANCHUK, J.D., TRAVASSOS, L.R. and TABORDA, C.P., 2011. Isolation of Histoplasma capsulatum from bats in the urban área of São Paulo State, Brazil. Epidemiology and Infection, vol. 139, no. 10, pp. 1642-1644. http://dx.doi.org/10.1017/S095026881000289X. PMid:21205438.

EMMONS, C.W., 1958. Association of bats with Histoplasmosis. Public Health Reports, vol. 73, no. 7, pp. 590-595. http://dx.doi. org/10.2307/4590196. PMid:13568009.

ESBÉRARD, C.E.L., 2003. Diversity of bats in conservation units in an area of regenerated forest at Atlantic Forest, Southeastern Brazil. Revista Brasileira de Zoociencias, vol. 5, no. 2, pp. 189-204.

FRANCIS, C.D. and BARBER, J.R., 2013. A framework for understanding noise impacts onwildlife: an urgent conservation priority. Frontiers in Ecology and the Environment, vol. 11, no. 6, pp. 305-313. http://dx.doi.org/10.1890/120183.

GIBSON, J.F. and JOHNSTON, S.A., 2015. Immunity to Cryptococcus neoformans and C. gattii during cryptococcosis. Fungal Genomics E' Biology, vol. 78, pp. 76-86. http://dx.doi.org/10.1016/j. fgb.2014.11.006. PMid:25498576.

GREER, D.L. and BOLAÑOS, B., 1977. Role of bats in the ecology of Paracoccidioides brasiliensis: the survial of Paracoccidioides brasiliensis in the intestinal tract of frugivorous bat, Artibeus literatus. Sabouraudia, vol. 15, no. 3, pp. 273-282. http://dx.doi. org/10.1080/00362177785380101. PMid:601662.

GROSE, E. and TAMSITT, J.R., 1965. Paracoccidioides brasiliensis recovered from the intestinal tract of three bats (Artibeus literatus) in Colômbia. Sabouraudia, vol. 4, no. 2, pp. 124-125. http://dx.doi.org/10.1080/00362176685190281. PMid:5896105.

HAN, H.J., WEN, H.L., ZHOU, C.M., CHEN, F.F., LUO, L.M., LIU, J.W. and YU, X.J., 2015. Bats as reservoirs of severe emerging infectious diseases. Virus Research, vol. 205, pp. 1-6. http:// dx.doi.org/10.1016/j.virusres.2015.05.006. PMid:25997928.

HANCE, P., GARNOTEL, E. and MORILLON, M., 2006. Chiroptera and zoonosis: an emerging problem on all five continents. Médecine Tropicale, vol. 66, no. 2, pp. 119-124. PMid:16775933. 
HASSELL, J.M., BEGON, M., WARD, M.J. and FÈVRE, E.M., 2017. Urbanization and Disease Emergence: Dynamics at the Wildlife-Livestock-Human Interface. Trends in Ecology $\mathcal{E}$ Evolution, vol. 32, no. 1, pp. 55-67. http://dx.doi.org/10.1016/j. tree.2016.09.012. PMid:28029378.

INSTITUTO BRASILEIRO DE GEOGRAFIA E ESTATÍSTICA - IBGE, 2010 [viewed 13 September 2013]. Censo demográfico. [online]. Available from: https://cidades.ibge.gov.br/brasil/mt/sinop/ panorama

KURTZMAN, C.P. and FELL, J.W., 1998. The yeasts: a taxonomic study. 5nd ed. Amsterdam: Elsevier Science, 2354 p.

MATTEDE, M.G.S., PIRAS, C., MATTEDE, K.D.S., FERRARI, A.T., BALDOTTO, L.S. and ASSBU, M.S.Z., 2015. Infecções urinárias causadas por Trichosporon spp em pacientes graves internados em unidade de terapia intensiva. Revista Brasileira de Terapia Intensiva, vol. 27, pp. 247-251.

MISRA, P.K. and ELANGOVAN, V., 2016. Light and scanning electron microscopic studies on food habit analysis of insectivorous bats. Advances in Life Sciences, vol. 5, pp. 3649-3654.

MOK, W.Y., LUIZÃO, R.C. and SILVA, M.S.B., 1982. Isolation off ungi from bats of the Amazon basin. Applied and Environmental Microbiology, vol. 44, no. 3, pp. 570-575. http://dx.doi. org/10.1128/aem.44.3.570-575.1982. PMid:6890326.

OYEKA, C.A., 1994. Isolation of Candida species from bats in Nigeria. Mycoses, vol. 37, no.9-10, pp. 353-355. http://dx.doi.org/10.1111/ myc.1994.37.9-10.353. PMid:7746295.

PACHECO, S.M., SODRÉ, M., GAMA, A.R., BREDT, A., SANCHES, C.E.M. and MARQUES, R.V., 2010. Morcegos urbanos: status do conhecimento e plano de ação para a conservação no Brasil. Chiroptera Neotropical, vol. 1, pp. 1-16.

PAGLIA, A.P., FONSECA, G.A.B., RYLANDS, A.B., HERRMANN, G., AGUIAR, L.M.S., CHIARELLO, A.G., LEITE, Y.L.R., COSTA, L.P., SICILIANO, S., KIERULFF, M.C.M., MENDES, S.L., TAVARES, V.C., MITTERMEIER, R.A. and PATTON, J.L. 2012. Lista anotada dos Mamíferos do Brasil. 2. ed. Belo Horizonte: Conservation International, $76 \mathrm{p}$.

PAZ, G.S., 2017. Pesquisa molecular de fungos patogênicos em quirópteros da região de Botucatu-SP. Botucatu: Programa de Pós-graduação em Medicina Veterinária, Universidade Estadual Paulista, 71 p. Dissertação de Mestrado em Medicina Veterinária.

PEIXOTO, J.V., ROCHA, M.G., NASCIMENTO, R.T.L., MOREIRA, V.V. and KASHIWABARA, T.G.B., 2014. Candidiasis: a literature review. Brasilian Journal of Surgery and Clinical Research, vol. 8, pp. 75-82.

PERUGINI, M., MANERA, M., GROTTA, L., ABETE, M.C., TARASCO, R. and AMORENA, M., 2011. Heavy metal ( $\mathrm{Hg}, \mathrm{Cr}, \mathrm{Cd}$, and $\mathrm{Pb}$ ) contamination in urban areas and wildlifereserves: honeybees as bioindicators. Biological Trace Element Research, vol. 140, no. 2, pp. 170-176. http://dx.doi.org/10.1007/s12011-010-8688-z. PMid:20393811.
PITT, J.I. and HOCKING, A.D., 2009. Fungi and food spoilage. 3rd ed. New York: Springer. . http://dx.doi.org/10.1007/978-0387-92207-2.

REIS, N.R., FREGONEZI, M.N., PERACCHI, A.L. and SHIBATTA, O.A., 2013. Morcegos do Brasil: guia de campo. 1. ed. Rio de Janeiro: Technical Books, $252 \mathrm{p}$.

REIS, N.R., PERACCHI, A.L., PEDRO, W.A. and LIMA, I.P., 2007. Morcegos do Brasil. 1. ed. Londrina: Universidade Estadual de Londrina, $253 \mathrm{p}$.

REZENDE, C.C., DUARTE, D.C. and FILIÚ, W.F.O., 2003. Pesquisa de Cryptococcus neoformans e Histoplasma capsulatum na gruta lago azul, Bonito - MS. In: Anais do XXVII Congresso Brasileiro de Espeleologia, 2003, Januária, MG. Campinas: Sociedade Brasileira de Espeleologia, pp. 140-144.

RUSSO, D. and ANCILLOTTO, L., 2015. Sensitivity of bats to urbanization: a review. Mammalian Biology, vol. 80, no. 3, pp. 205-212. http://dx.doi.org/10.1016/j.mambio.2014.10.003. PMid:32226358.

STONE, E.L., JONES, G. and HARRIS, S., 2009. Street lighting disturbs commuting bats. Current Biology, vol. 19, no. 13, pp. 1123-1127. http://dx.doi.org/10.1016/j.cub.2009.05.058. PMid:19540116.

SUGITA, T.K., KIKUCHI, K., MAKIMURA, K., URATA, K., SOMEYA, T., KAMEI, K., NIIMI, M. and UEHARA, Y., 2005. Trichosporon species isolated from guano samples obtained from bat-inhabited caves in Japan. Applied and Environmental Microbiology, vol. 71, no. 11, pp. 7626-7629. http://dx.doi.org/10.1128/AEM.71.11.76267629.2005. PMid:16269819.

TENCATE, L.N., TÁPARO, C.V., CARVALHO, C., BOSCO, S.M.G., QUEIROZ, L.H. and SILVA, D.C., 2012. Study of gastrointestinal fungal flora of bats (Mammallia, Chiroptera) of the northwest region of São Paulo state: zoonotic potential. Research in Veterinary Science, vol. 49, pp. 146-152. http://dx.doi.org/10.11606/issn.2318-3659. v49i2p146-152.

VELOSO, S.S.C., FERREIRO, L., PACHECO, S.M., SILVA, R.R.P., SOUZA, E.C. and MACHADO, G., 2014. Pneumocystis spp. and Histoplasma capsulatum in Bats Lungs in Southern and Midwestern Regions of Brazil. Acta Scientiae Veterinariae, vol. 42, pp. 1-7.

VOYRON, S., LAZZARI, A., RICCUCCI, M., CALVINI, M. and VARESE, G.C., 2011. First mycological investigation on italian bats. Hystrix: Italian Journal of Mammalogy, vol. 22, pp. 189-197. http://dx.doi. org/10.4404/hystrix-22.1-4481.

WATANABE, S., 2010. Asymptotic equivalence of Bayes cross validation and widely applicable information criterion in singular learning theory. Journal of Machine Learning Research, vol. 11, pp. 3571-3594.

ZANELLA, J.R.C., 2016. Zoonoses emergentes e reemergentes e sua importância para saúde e produção animal. Agricultural Research, vol. 51, pp. 510-519. http://dx.doi.org/10.1590/S0100$204 X 2016000500011$. 